\title{
A T S 理論の活用による運転者教育用の モデルビデオの作成
}

吉田信爾 (東北学院大学教養学部)

Making short films for driver education using th ATS theory

Shinya Yoshida (Tohoku Gakuin University)

\section{1. 問題の背景と研究のねらい}

D. A. Norman（1981）は日常生活におけるし 損ないのエラー（スリップ）を分類すると共 に日常的な行動をとらえる枠組みとしてのA T S (Activation-Trigger-Schema system) 理論を提唱した。そのAT S 理論の仮定を仁 平（1990）は以下のように要約した。

(1)熟練行為にはスキーマが形成される。

(2)スキーマは階層的な構造をもつ。

(3)意図の形成とは最高次のスキーマの活性化 である。

(4)親 (全体) スキーマの活性化にともなって 子（部分）スキーマは自動的に活性化される。 (5)関連するスキーマにも活性化が波及する。 (6)活性化されたスキーマがトリガーされて、 行為が遂行される。

ここでいうノーマンのスキーマは「感覚運 動的な知識構造」であり、具体的な行為の手 順までも指定した汎用的なプログラムである。 そして、スキーマは「外界に開かれたゆるや かな自動性」をもっている。そして複数スキ 一マが並行的に活動することがある故に行為 の迅速性が確保される反面、スリップなどが 生じるというのである。

吉田（1991）はこのAＴＳ理論の運転行動 への適用する際の問題点を検討し、運転はい わば自動化したプログラムであるさまざまの スキーマからなるとした。そこでは、スキー マは安全運転のために各運転者がもっている 注意事項集のようなものといえた。
ノーマンのスキーマ論で運転中のミスや事 故を考察するとき有用な点の一つは、スキー マ (知識) そのものが久如していたケースと、 スキーマはあったが、それが十分に活性化 （あるいは起動）しなかったエラーとを区別 することである。それによって運転者への教 㕕の方法が異なるからである。

今回は、前者のスキーマそのものに問題が ある例をとりあげ、そのスキーマの欠落部分、 あるいは日常的な繰り返しの中で本来の意味 を失ってしまった行動を明示するようなビデ オを作成し、運転者のスキーマの再体制化を 促し、運転者教育に貢献することを研究のね らいとした。

その際、ビテオ作成にあたっては次の 2 点 を心がけた。第一は、スキーマは概略的なも のであるから、それをビデオで示す際も要所 要所を簡略化して映像化すること、すなわち 簡潔であること。第二は、交通安全に限らず 安全教育は、とかく「確実に確実に」と当り 前のことを繰り返し強調するだけに終わる傾 向があった。そこで、ビテオには、おもしろ み、おかしみ、ユーモアの要素が含まれ、固 いだけの印象にならないようにした。

\section{2.ビデオ例《一時停止票識のある交差点》}

ここでは見通しのきかない一時停止標識の ある交差点の通行を例にした。このような地 点では停止線があるにもかかわらず、多くの 車は停止線では止まらず、それを越えた地点 が最徐行筒闽になり、そこで左右の確認がな 
されるというのが典型と推定される。停止線 で止まらないのはそこで止まっても左右の見 通しがきかないからで、おそらく、そこでは

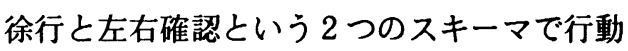
がなされている。

このような運転者において久落しているの は、自車を見せるという視点である。自分で 左右を「見る」ことが優先し、停止線通りに 止まるの無意味とする。本来停止線で止まる のは、そこで停車し発進することで最徐行の 状態で左右の通行者に自車の存在を示すこと にある。自動車学校でもそのように教えられ てはいても実際には停止線は形式的な遵守事 項となり、免許取得後には「見る」ためには 無意味な仕切り線と思われるようになる。

そこで、ビデオでは「見る」より「見せる」 ことを強調し、「見せるスキーマ」として次 の 3 項目を時間的展開順に文字表示した。

1. ブレーキ 2 回・・追乫防止

2 . 停止線でロー・・捕まり防止

3. そろりと出る・・・衝突防止

1 のブレーキ 2 回は追突を防止するために 後乃に見せる。2 は停止線で静止すれば法規 通りであるが、ギアをローに落とすで充分と し、これは警察に見せて、停止線超過で捕ま るのを防止するとした。最後にそろりとゆっ くり出るのは横からの交差車両との衝突防止 だが、自転車歩行者を含む横の方向の通行者 に自分を見せることを説く。

全て、見せる対象をもち、見通しのきかな い一時停止標識のある交差点通行時の注意事 項を 3 点に集約した。短時間のビデオでは 3 が限界項目数と思われた。その 3 事項は「自 車の存在を見せる、知らせる」というスキー マの下位項目でもあるわけである。

ここでは「左右を見る」は敢えて省略した。 左右を見る行為は歩行者としても教育されて いる古いスキーマであるので、交差点ではほ ぼ自動的に起動すると予測できたので、見せ るスキーマに集約し、「見る」方は外した。

\section{3. モデルビデオの性格}

このようなモデルビテオ（デモテープ）を 作成するとき、それが現実に展開するスキー マのモテルか、形式をそろえた単なる模式図 であるかが問われる。今回のは明らかに後者 である。なぜなら、左右の確認等、そこで実 行されるスキーマの全てを網羅しているわけ ではない。スキーマは紐かく階層化されてい ると考えられるので、細分化されたスキーマ をどこまで示すかは問題である。

今回作成のモデは、見通しのきかない一 時停止標識のある交差点で、忘れられがちな スキーマを新知識として提示し、欠落部分を 指摘するものである。運転者からみれば「こ んな運転、考え方もあるのか」と思えるよう なビテオ内容にし、運転者の新しいスキーマ の統合と認知的な再体制化を促すことを目的 とする。

運転に関する諸々のスキーマ間の関係がど のようになっているかは調查研究中であるが、 現段階では、スキーマは運転の場面ごとに形 成されていると考えられるので、今回のよう なビテオは多種類の場面でそれぞれに必要と される。例えば、左折場面、大きな交差点で 右折場面、雪道や凍結道路、坂道登坂という ように状況や課題によって、それぞれ必要と され、またとかく実行されないスキーマを検 討し、モデル化していく計画である。

\section{【文献】}

仁平義明 1990 からだと意図が乘離すると きースリップの心理学的理論- 佐伯㭌 ・佐々木正人 アクティブ・マインド 東 大出版

Norman, D. A. 1981 Categorization of action slips. Psychological Review, 88, 1-15.

吉田信爾 1991 ノーマンの A T S 理論の運 転行動への適用 産業・組繀心理学会第 7 回大会発装論文集 65-67. 